\title{
PENDIDIKAN KARAKTER MAHASISWA STAI DDI KOTA MAKASSAR DALAM PENDIDIKAN FORMAL
}

\author{
HALAWATI \\ 17210008 \\ STAI DDI KOTA MAKASSAR \\ Halawatihalwa99@gmail.com
}

\begin{abstract}
ABSTRAK
Manyangkut Pendidikan karakter di beberapa negara sudah mendapatkan prioritas sejak pendidikan dasar dimulai. Namun di Indonesia, pendidikan karakter masih dipandang sebagai wacana dan belum menjadi bagian yang terintegrasi dalam pendidikan formal. Artikel ini membahas tentang pentingnya pendidikan karakter dalam system pendidikan formal. Dimulai dengan melihat contoh manfaat pendidikan karakter di negara lain seperti Amerika dan Cina. Kemudian, dilanjutkan dengan usaha-usaha yang dilakukan oleh Jurusan Teknik Industri UK Petra untuk merancang pendidikan karakter yang sistematis dan terintegrasi dalam kurikulum bagi mahasiswa sebagai persiapan menuju ke dunia kerja. Usaha tersebut antara lain penetapan pendidikan karakter sebagai salah satu rencana strategis jurusan, penetapan tim, perancangan dan pelaksanaan program pendidikan karakter, evaluasi, serta usaha perbaikan terus menerus.
\end{abstract}

Kata kunci: definisi karakter, perancangan pendidikan, hambatan-hambatan.

\section{PENDAHULUAN}

Menurut pendapat para ahli Karakter seorang individu terbentuk sejak dia kecil karena pengaruh genetik dan lingkungan sekitar. Proses pembentukan karakter, baik disadari maupun tidak, akan mempengaruhi cara individu tersebut memandang diri dan lingkungannya dan akan tercermin dalam perilakunya sehari-hari. Universitas sebagai lembaga pendidikan tinggi adalah salah satu sumber daya yang penting.Sambil mengevaluasi tujuan kita, sangatlah penting untuk menyusun kurikulum yang secara jelas memuat pendidikan karakter. Namun, semakin singkatnya waktu studi serta mahalnya biaya pendidikan mendorong mahasiswa menjadi mahasiswa yang pragmatis dalam mencapai cita-citanya.

Hal ini mengakibatkan kegiatan-kegiatan sosial menjadi semakin sedikit. Dorongan untuk berinteraksi secara sosial dengan sesama sangat kurang, padahal hal 
ini sangat penting dalam pembentukan karakter. Berdasarkan observasi singkat kepada para alumni, ditemukan bahwa banyak alumni yang ternyata tidak siap terjun ke dunia kerja. Daya tahan dan kemampuan beradaptasi dalam lingkungan dan tekanan pekerjaan sering dikeluhkan sebagai kendala utama yang menghambat Pengembangan karir. Menyadari bahwa karakter individu tidak bisa dibentuk hanya melalui satu atau dua kegiatan saja, maka akan disusun kurikulum pembinaan karakter yang berkesinambungan dan terintegrasi dalam perkuliahan, dimana proses tersebut juga melibatkan dosen, karyawan, dan lembaga lain dalam universitas, sehingga manfaat pembinaan karakter dapat dirasakan.

\section{PENTINGNYA PENDIDIKAN KARAKTER}

\subsection{Mengenai Definisi Karakter}

Pendidikan karakter yaitu mengajarkan kebiasaan cara berpikir dan perilaku yang membantu individu untuk hidup dan bekerja bersama sebagai keluarga, masyarakat, dan bernegara dan membantu mereka untuk membuat keputusan yang dapat dipertanggungjawabkan. Karakter yang menjadi acuan seperti yang terdapat dalam The Six Pillars of Character yang dikeluarkan oleh Character Counts! Coalition ( a project of The Joseph Institute of Ethics). Enam jenis karakter yang dimaksud adalah sebagai berikut:

a. Trustworthiness, bentuk karakter yang membuat seseorang menjadi: berintegritas, jujur, danloyal.

b. Fairness, bentukkarakteryangmembuatseseorangmemilikipemikiranterbukas ertatidaksuka memanfaatkan oranglain.

c. Caring, bentuk karakter yang membuat seseorang memiliki sikap peduli dan perhatian terhadap orang lain maupun kondisi sosial lingkungan sekitar.

d. Respect,bentuk karakter yang membua tseseorang selalu menghargai dan menghormati orang lain.

1.2. Pendidikan Karakter juga telah ditanamkan di Negara Lain Sumber yang ada menunjukkan bahwa pendidikan karakter di beberapa negara dimulai sejak pendidikan dasar, seperti di Amerika Serikat, Jepang, Cina, dan Korea. Apakah ada bukti bahwa implementasi pendidikan karakter yang tersusun secara sistematis betul-betul memiliki efek positif dalam pencapaian akademis? Jawabannya ya. Berikut akan diberikan abstrak dari beberapa stud ihasil 
pendidikan karakter di Amerika dan Cina. Pemerintah Amerika sangat mendukung program pendidikan karakter yang diterapkan sejak pendidikan dasar. Hal ini terlihat pada kebijakan pendidikan tiap-tiap negara bagian yang memberikan porsi cukup besar dalam perancangan dan pelaksanaan pendidikan karakter. Hal ini bisa terlihat pada banyaknya sumber pendidikan karakter di Amerika yang bisa diperoleh. Kebanyakan, program-program dalam kurikulum pendidikan karakter tersebut menekankan pada experiental study sebagai sarana pengembangan karaktersiswa.

Dalam penelitiannya, Mr. Doug Monk dari Kingwood Middle School di Humble, Texas, membandingkan evaluasi para guru terhadap murid sebelum dan sesudah diimplementasikannya kurikulum Lessons in Character. Dalam kurikulum yang lebih banyak mengajak murid untuk berinteraksi dalam kegiatan-kegiatan sosial dan mengembangkan kepekaan mereka, telah memberikan dampak positif dalam perubahan cara belajar, kepedulian dan rasa hormat terhadap para staff sekolah, dan meningkatnya keterlibatan para murid secara sukarela dalam proyek-proyek kemanusiaan(Brooks,2005). Dibeberapa negarasepert iCina, dalam program reformasi pendidikan yang diinginkan oleh Deng Xiaoping pada tahun 1985, secara eksplisit diungkapkan tentang pentingnya pendidikan karakter: Throughout the reform of the education system, it is imperative to bear in mind that reform is for the fundamental purpose of turning every citizen into a man or woman of character and cultivating more constructive members of society $(\mathrm{Li}, 2005)$. Karena itu program pendidikan karakter telah menjadi kegiatan yang menonjol di Cina yang dijalankan sejak jenjang pra-sekolah sampai universitas.

Menurut Li Lanqing, seorang politikus dan birokrat Cina yang mempunyai pemahaman yang komprehensif dan mendalam tentang pendidikan menenkankan tentang bahayanya sistem pendidikan yang terlalu menekankan hapalan, drilling, dan cara mengajar yang kaku, termasuk sistem pendidikan yang berorientasi hanya untuk lulus dalam ujian. Sebagai hasilnya, Cina yang relatif baru bangkit dari keterpurukan ekonomi, sosial, dan budaya akibat Revolusi Kebudayaan yang dijalankan oleh Mao, bisa begitu cepat mengejar ketertinggalannya dan menjadi negara yang maju. Presiden Jiang Zemin sendiri pernah mengumpulkan semua anggota Politburo khusus untuk membahas bagaimana mengurangi beban pelajaran siswa melalui adopsi sistem pendidikan yang patut secara umur dan menyenangkan, dan pengembangan seluruh aspek dimensi manusia; aspek kognitif (intelektual), karakter, aestetika, dan fisik (atletik) (Li,2005). 


\section{PERANCANGAN PENDIDIKAN KARAKTER DI STAI KOTAMAKASSAR}

Proses pendidikan karakter di STAI DDI KOTA MAKASSAR selama ini belum banyak menyentuh pembinaan karakter Maha siswa. Pendidikan di perguruan tinggi hanyalah beberapa tahun saja sebelum Maha siswa masuk ke dunia kerja, sehingga pendidikan dasar dan menengah yang seharusnya lebih banyak berperan dalam pendidikan karakter. Sayangnya pendidikan karakter di tingkat dasar sampai menengah sekolah-sekolah di Indonesia belum betul-betul mendapat tempat dibandingkan pendidikan akademis. Masih banyak sekolah yang walau menyadari bahwa karakter itu penting, belum melakukan pembinaan serius untuk mengembangkan karakter yang positif. Hal ini mengakibatkan input yang diterima perguruan tinggi bukanlah mahasiswa yang siap untuk dididik karakternya.

Di tengah segala kekurangan dan hambatan yang ada di STAI DDI ini tetap mencoba untuk menyusun sistem pendidikan yang bertujuan meningkatkan kompetensi akademis dan juga karakter Maha siswanya. Pendidikan karakter di STAI DDI INI lebih dikenal dengan nama pengembangan karakter (character development (CD)). Penetapan (CD) sebagai salah satu rencana strategis dan penyusunan tim (CD) menjadi bukti komitmen STAI DDI Berikut adalah garis besar proses pendidikan di STAI DDI. Masukan adalah calon mahasiswa dan mahasiswa di jurusan ini. Dengan beragam latar belakang, motivasi, dan kemampuan mahasiswa melalui proses belajar mengajar yang berdasarkan nilainilai islami. Sebagai keluaran yang diharapkan adalah alumni yang memiliki kompetensi dan karakter yang baik. Gambar 1. Proses Belajar Mengajar di Jurusan TI UKP Elemen sistem yang berpengaruh terhadap keluaran jurusan STAI DDI adalah:

- Jurusan: Ktua Jurusan, Sekretaris Jurusan, petugasa dministrasi

- Dosen

- Mahasiswa baru dan mahasiswa senior

- Lembaga kemahasiswaan UKP

- Unit penunjang UKP

- Keluarga mahasiswa

Secara umum, rencana pengembangan karakter dapat dibagi menjadi tiga tahap, yaitu: 
- Tahap Awal. Pengembangan karakter menekankan pada kesadaran perubahan status mahasiswa dari kehidupan siswa menjadi mahasiswa yang memiliki serang kaian konsekuensi dan tanggung jawab kedewasaan.

- Tahap Madya. Tahapan ini menekankan pada proses belajar secara mandiri dari mahasiswa, melatih mahasiswa untuk bersosialisasi dengan orang lain dan mengembangkan kepekaan mereka.

- TahapAkhir.Pada tahap ini proses pengembangan lebih difokuskan pada profil lulusan yang diharapkan oleh industri. Baik tahap awal, madya ,maupun tahap akhir, pengembangan karakter yang dilakukan senantiasa mengacu pada 6 karakter yang telah disebutkan pada bagian 1.1. dan pelaksanaannya akan melibatkan elemen-elemen sistem diatas.

Berbagai Identifikasi Karakter Mahasiswa Materi pengembangan karakter yang akan dijadikan tujuan dalam program ini ditentukan berdasarkan hasil identifikasi karakter mahasiswa. Karakter adalah variabel yang sangat sulit diukur, bahkan dengan alat psikotes sekalipun. Bagaimanapun juga untuk dapat merancang suatu program pembinaan karakter dengan tepat, harus dilakukan pengukuran terhadap karakter mahasiswa. Sebuah perangkat psiko-tesuntuk mengukur karakter mahasiswa sesuai Six Pillars of Characters sudah pernah dirancang (Hendra dan Fransisca, 2003), dan perangkat ini yang akan digunakan untuk melakukan pengukuran.

Alat ini telah dirancang untuk memberikan gambaran karakter individu menurut SixPillar: Trustworthiness, Fairness, Caring, Respect, Citizenship, dan Responsibility. Output dari tes ini adalah nilai rendah, sedang, dan tinggi untuk masing-masing karakter setiap mahasiswa. Hasil ini akan dibobotkan dan diperoleh total skor tiap karakter untuk keseluruhan mahasiswa yang diuji.

Dari hasil tes tersebut maka diketahui secara umum untuk mahasiswa angkatan 2003 mempunyai kecenderungan nilai yang rendah untuk karakter Caring, Respect, dan Citizenship. Maka, ketiga point karakter inilah yang dijadikan acuan dalam menyusun materi dalam program pembinaan karakter mahasiswa angkatan 2003. 0 20406080100120140160180 totalskor 1 Six Pillars of Character Perbandingan Karakter Mahasiswa Trustw orth Fairness CaringRespect.

Menyangkut tentang Pelaksanaan dan Evaluasi Penyusunan program bagi kurikulum pengembangan karakter yang sistematis dan terintegrasi dalam setiap aspek pendidikan di jurusan TI membutuhkan proses dan waktu yang cukup panjang. Sebagai pilot project, TI memprogramkan pengembangan karakter berupa 
kegiatan live in di sebuah desa selama beberapa minggu dan pekan kepedulian bagi mahasiswa TI angkatan2003.

Setelah program dilaksanakan, maka harus dilakukan evaluasi kegiatan dan pengukuran untuk menilai efektivitas dari program yang sudah dilakukan. Kesulitan yang dihadapi dalam hal ini adalah, seperti sudah dijelaskan sebelumnya bahwa karakter berkembang melalui sebuah proses, bukan hanya even yang berpengaruh sesaat saja. Oleh karena itu, tentunya tidak valid jika tes karakter kembali diterapkan sesaat setelah program selesai dijalankan.

Namun berdasarkan hasil observasi dengan mahasiswa peserta kegiatan live in dan pekan kepedulian, kebanyakan dari mereka merasa mendapatkan pengalaman baru dan berbeda yang membuka mata mereka akan cara hidup yang jauh berbeda dengan yang mereka jalani selama ini. Hal ini menyadarkan mereka tentang pentingnya menghargai orang lain, jerih payah, dan hasil karyanya, dan masih banyak hal lain yang membuat mereka lebih menghargai hidup yang sudah mereka terima.Kegiatan ini juga membawa dampak positif dalam cara pandang dan perilaku mereka, yang dapat terlihat dari keseharian mereka dalam berinteraksi dengan lingkungan mereka, khususnya di jurusan tarbiyah.

Secara jangka panjang, parameter yang dapat menjadi indikator manfaat pengembangan karakter bagi jurusan tarbiyah disesuaikan dengan strategi jurusan adalah retention rate (semakin sedikitnya mahasiswa yang putus kuliah karena persoalan non financial), banyaknya pengabdian masyarakat yang dilakukan baik oleh dosen maupun mahasiswa, lama studi, dan kemampuan bertahan di pekerjaan.

\section{HAMBATAN -HAMBATAN}

Belum membudayanya pendidikan karakter di Indonesia menjadi tantangan tersendiri bagi upaya pengembangannya. Hal ini menyebabkan baik pendidik maupun peserta didik belum terbiasa dengan model pendidikan karakter. Dibutuhkan komitmen yang kuat untuk bisa merancang dan melaksanakan program ini dengan efektif. Selain itu, sumber-sumber informasi yang tersedia lebih banyak mengacu model di negara lain yang budaya dan kebutuhannya relatif berbeda denganIndonesia.

\section{KESIMPULAN}

Pendidikan karakter penting bagi pertumbuhan individu menjadi manusia yang seutuhnya dan sebaiknya dilakukan sejak dini. Namun bukan berarti jika pendidikan dasar belum mengakomodasi pendidikan karakter, perguruan tinggi juga merasa tidak perlu untuk menyelenggarakannya. Pentingbagi perguruan tinggi untuk tidak 
hanya memperhatikan kebutuhan kompetensi akademis mahasiswa, tapi juga pembinaan karakternya agar lulusan menjadi lulusan yang siap secara akademis dan berkarak terbaik. Keinginan jurusan tarbiyah untuk membina karakter mahasiswa telah dituangkan ke dalam rencana strategisnya dan perancangan program yang sistematis dan terintegrasi sudah mulai dilakukan. Sebagai pilotproject, dilakukan program livein dan pecan kepedulian. Hasil dari program ini memang tidak dapat langsung merubah karakter mahasiswa, namun telah memberikan warna positif dalam suasana perkuliahan. Untuk ke depannya, perancangan pendidikan karakter harus terus dilakukan dengan komitmen yang tinggi dan dilakukan usaha perbaikan terusmenerus. 


\section{Daftar Pustaka}

1. Balitbang puskur. 2010. Pengembangan pendidikan budaya dan karakter bangsa: pedoman sekolah. Jakarta: kemdiknas balitbang puskur.

2. Deal, terrence e. Dan kent d. Peterson. 2009. Shaping school culture: pitfall, paradoxes, and promises. San francisco: josses-bass.

3. Darmiyati zuchdi (ed.). 2011. Pendidikan karakter dalam perspektif teori dan praktik. Yogyakarta: uny press.

4. Lickona, thomas. 1991. Educating for character: how our school can teach respect and responsibility. New york: bantam books.

5. ------. "make your school a school of character", dalam character matters, www.Cortland.edu/character. Diunduh, 10 oktober 2011.

6. Ryan, kevin dan karen e. Bohlin. 1999. Building character in schools: practical ways to bring moral instruction to life. San francisco: jossey-bass a wiley imprint.

7. Shariati, ali. 1996. Tugas cendekiawan muslim. (terjemahan m. Amien rasi). Jakarta: srigunting

8. Suyata. 2011. "pendidikan karakter: dimensi filosofis", dalam darmiyati zuchdi (ed.). 2011.

9. Pendidikan karakter dalam perspektif teori dan praktik. Yogyakarta: uny press.

10. Arsyam, m. (2020). Pengaruh kemampuan supervisional kepala sekolah dan peran komite sekolah terhadap kinerja guru sma negeri di kota makassar.

11. Arsyam, m., \& umar, k. (2020). Manusia sebagai pendidik perpektif islam dan barat.

12. Arsyam, m., jumliadi, m. H., \& alwi, a. M. S. (2020). Pembelajaran dirumah dalam lingkungan keluarga di tengah pandemi covid 19.

13. Herianto, h., \& hamid, n. (2020). Analisis proses berpikir kreatif dalam pemecahan masalah geometri berdasarkan gaya kognitif reflektif dan impulsif siswa. Pedagogy: jurnal pendidikan matematika, 5(2), 38-49.

14. Herianto, h. (2020). Teknik menulis artikel konseptual.

15. Herianto, h. (2019). PENERAPAN METODE ACCELERATED LEARNING FOR THE 21st CENTURY DALAM MENINGKATKAN HASIL 
BELAJAR MATEMATIKA SISWA. Delta: Jurnal Ilmiah Pendidikan Matematika, 7(2), 37-50.

16. Jusmiana, A., Herianto, H., \& Awalia, R. (2020). Pengaruh Penggunaan Media Audio Visual Terhadap Hasil Belajar Matematika Siswa Smp Di Era Pandemi Covid-19. Pedagogy: Jurnal Pendidikan Matematika, 5(2), 1-11 


